\title{
PENGARUH KOMISARIS ASING DAN DIREKSI ASING TERHADAP STRUKTUR MODAL
}

\author{
Tyasha Ayu Melynda Sari \\ tyasha.ayu.melynda-2018@feb.unair.ac.id \\ Mahasiswa Magister Akuntansi, Universitas Airlangga, Surabaya
}

\begin{abstract}
This study aims to examine the influence of Foreign Commissioner and Foreign Directors on the Capital Structure. Determination of the sample in this study using a purposive sampling method. Based on the sampling criteria obtained 31 observations of manufacturing companies listed on the Indonesia Stock Exchange during 2012-2018. This study uses multiple linear regression analysis techniques with SPSS (Statistical Product and Service Solutions). The results showed foreign directors and commissioners significant effect on capital structure. This happens because the company will maintain funding conditions that can endanger operational activities and the company sustainability. Foreign commissioners and foreign directors who have broader scientific expertise can be utilized by the company when implementing its expansion movement from a variety of strategic market share that it has more ability and knowledge to carry out supervision and policy making by managerial. This study also uses control variables Growth of Sales (Growth), Effective Tax Rate (ETR), Dividend Payout Ratio (DPR), Managerial Ownership (KM), and Institutional Ownership (KI). The results show that only variable Dividend Payout Ratio (DPR) significant effect on the Capital Structure, and Growth of Sales, Effective Tax Rate (ETR), Managerial Ownership (KM), and Institutional Ownership (IC) no significant effect on Capital Structure
\end{abstract}

Key words: foreign director; foreign commissioner; capital structure.

\begin{abstract}
ABSTRAK
Penelitian ini bertujuan untuk menguji pengaruh antara Komisaris Asing dan Direksi Asing terhadap Struktur Modal. Penentuan sampel pada penelitian ini menggunakan metode purposive sampling. Berdasarkan kriteria pengambilan sampel diperoleh sebanyak 31 pengamatan perusahaan manufaktur yang terdaftar di Bursa Efek Indonesia selama tahun 2012-2018. Penelitian ini menggunakan teknik analisis regresi linier berganda dengan alat bantu SPSS (Statistical Product and Service Solutions). Hasil penelitian menunjukkan bahwa komisaris dan direksi asing berpengaruh signifikan terhadap struktur modal karena perusahaan akan menjaga kondisi pendanaan yang dapat mengganggu kegiatan operasinal dan keberlanjutan hidup perusahaan. Komisaris asing dan direksi asing yang mempunyai keahlian ilmu pengetahuan yang lebih luas dapat dimanfaatkan perusahaan pada saat mengimplementasikan pergerakan ekspansinya dari berbagai macam pangsa pasar yang strategis sehingga memiliki kemampuan dan pengetahuan yang lebih untuk melakukan pengawasan dan pembuatan kebijakan yang dilakukan oleh manajerial. Penelitian ini juga menggunakan variabel kontrol yaitu Pertumbuhan Penjualan (Growth), Effective Tax Rate (ETR), Dividend Payout Ratio (DPR), Kepemilikan Manajerial (KM), dan Kepemilikan Institusional (KI). Hasilnya menunjukkan bahwa hanya Dividend Payout Ratio (DPR) berpengaruh signifikan terhadap Struktur Modal, dan Pertumbuhan Penjualan (Growth), Effective Tax Rate (ETR), Kepemilikan Manajerial (KM), dan Kepemilikan Institusional (KI) berpengaruh tidak signifikan terhadap Struktur Modal.
\end{abstract}

Kata kunci: direktur asing, komisaris asing, struktur modal.

\section{PENDAHULUAN}

Persaingan usaha yang tinggi yang terjadi saat ini mengharuskan perusahaan untuk mempunyai strategi yang tepat untuk mempertahankan kelangsungan hidup untuk masa yang akan datang. Manajemen 
yang berperan aktif dalam kegiatan operasional perusahaan mempunyai tugas untuk mengembangkan perusahaan dengan memanfaatkan modal yang dimiliki seefektif dan seefisien mungkin, maka perusahaan dapat mencapai tujuan utamanya yaitu mensejahterakan pemilik (Denziana dan Yunggo, 2017).

Perusahaan manufaktur merupakan perusahaan yang memiliki banyak kegiatan proses bisnis yaitu dari barang mentah, barang setengah jadi, dan barang jadi sehingga memerlukan banyak alternatif dalam proses pendanaan untuk perusahaannya. Setiap perusahaan membutuhkan dana untuk menjalankan kegiatan usahanya. Pendanaan perusahaan dapat diperoleh dari internal dan eksternal perusahaan. Jika perusahaan menggunakan sumber internal maka dapat mengurangi sifat ketergantungan kepada pihak eksternal. Perusahaan dalam keadaan berkembang, maka perusahaan dituntut untuk mencari alternatif pendanaan selain dari internal perusahaan yaitu sumber pendanaan eksternal perusahaan. Ketika perusahaan menggunakan sumber eksternal maka memilih pendanaan berasal dari utang dalam waktu jangka pendek maupun jangka panjang sebelum terakhir menerbitkan saham.

Keputusan dalam menentuksn sumber pendanaan adalah salah satu proses pengambilan keputusan yang mempunyai peran penting bagi perusahaan manufaktur, terutama mempunyai dampak untuk keberlangsungan hidup perusahaan. Selain itu, manajemen dalam pengambilan keputusan penggunaan utang dihadapkan pada dua pilihan dikaitkan dalam dua hal penting, yaitu pertama kemudahan yang didapatkan perusahaan dalam mendapatkan sumber pinjaman sehingga dapat memberikan kesempatan manajemen untuk melakukan pinjaman, dan posisi keuangan perusahaan manufaktur dapat berpengaruh terhadap peran kreditur untuk memberikan dana kepada perusahaan manufaktur. Keputusan manajemen dalam menggunakan utang merupakan upaya memperoleh keuntungan yang setinggi mungkin dari penggunaan utang yang diperoleh dari mengurangi biaya pajak dan pembayaran bunga (Firmanullah dan Darsono, 2017).

Seorang manajemen ketika mengambil suatu keputusan pendanaan, maka akan dihadapkan oleh suatu pilihan. Pilihannya antara lain, apakah sumber dana yang akan digunakan berasal dari internal atau dari sumber eksternal perusahaan. Sumber pendanaan dari internal dapat berupa laba ditahan sedangkan untuk sumber pendanaan dari eksternal dapat berupa utang atau penerbitan saham baru. Apabila pendanaan yang digunakan perusahaan berupa utang, maka hal tersebut menunjukkan bahwa sumber pendanaan yang berasal dari internal tidak mencukupi dalam proses kegiatan perusahaan. Ketika utang perusahaan lebih besar, itu menunjukkan bahwa perusahaan dapat menimbulkan sebuah risiko perusahaan dari sisi likuiditas keuangan juga akan menjadi tinggi. Oleh karena itu dibutuhkan suatu keputusan yang tepat dalam menentukan sumber pendanaan (Susila dan Prena, 2019).

Struktur modal adalah perbandingan antara sumber jangka panjang yang bersifat utang dengan modal sendiri (Husnan, 2000). Adanya keuntungan dan kerugian dalam menggunakan ekuitas maupun utang yang tinggi akan memerlukan adanya analisis yang digunakan untuk menentukan jumlah proporsi penggunaan ekuitas dan utang dalam struktur modal supaya tercapainya struktur modal yang optimal (Astuti et al., 2015). Menurut Brigham (2011) struktur modal yang optimal merupakan kombinasi antara utang dan ekuitas yang dapat memaksimalkan harga saham. Perusahaan dapat menggunakan modal ekuitas atau utang untuk membiayai aset perusahaan karena pembiayaan terbaik adalah campuran antara utang dan ekuitas. Jika bunga merupakan bukan pengurang pajak, maka pemilik perusahaan akan tidak memperdulikan tentang penggunakan utang atau ekuitas dalam memenuhi kebutuhan pendanaan, tetapi jika bunga adalah pengurang 
pajak, para pemilik akan memaksimalkan nilai perusahaan dengan menggunakan seluruh utang (Azhagaiah dan Gavoury, 2011). Pada saat ini, Indonesia memasuki masa perekonomian yang sedang maju dan modern maka tidak heran jika banyak tenaga kerja asing yang akan memasuki wilayah Indonesia dalam proses bisnis, baik dalam penanaman saham atau mendirikan perusahaan (Saragih, 2019). Menurut Peraturan Presiden (Perpres) Nomor 20 Tahun 2018 tentang Penggunaan Tenaga Kerja Asing, Komisaris Indonesia dapat dijabati oleh warga asing tetapi tidak memasuki bidang personalia seperti yang tertera di Pasal 4 ayat (1) dan (2).

Corporate governance dapat tercipta dengan baik maka perlu adanya pengawasan terhadap internal perusahaan atau pengelolaan perusahaan. Mekanisme internal adalah unsur yang selalu diperlukan dalam perusahaan dan sangat berperan dalam mengelola perusahaan (Agustina, 2009), diantaranya dewan direksi asing dan komisaris asing. Menurut Kementerian Ketenagakerjaan (Kemenaker) RI, untuk statistik tenaga kerja asing tahun 2018 sebesar 95.335 orang mengalami peningkatan $10,88 \%$ dibandingkan tahun 2017. Jumlah ini dibandingkan dengan jumlah penduduk di Indonesia yang berkerja atau produktif pada Agustus 2018, sebesar 124,01 juta jiwa menunjukkan persentase $0,08 \%$ (Badan Pusat Statistik). Jumlah persentase tersebut lebih kecil dibanding dengan jumlah pekerja asing di negara tetangga seperti Malaysia $12 \%$, Singapura $60 \%$, Qatar $94,5 \%$, dan Uni Emirat Arab 96\% (Lampost.co).

Menurut Statistik Tenaga Kerja Asing tahun 2018, jumlah tenaga asing di Indonesia masih termasuk sangat kecil dibanding dengan tenaga kerja Indonesia (TKI) yang bekerja di luar negeri. Data Bank Dunia menunjukkan bahwa pada akhir tahun 2017 sebesar 9 juta jiwa. Jumlah tersebut yang tersebar meneyeluruh di beberapa negara misalnya sebesar 55\% di Malaysia, 13\% di Arab Saudi, 10\% di Tiongkok dan Taipei, sisanya di negara-negara lain (Kompas.com).
Keberadaan tenaga kerja asing yang masuk dewan perusahaan tidak hanya membawa keterampilan dan pengetahuan yang berbeda, adanya nilai norma dan pemahaman yang berbeda berdasarkan negara mereka berasal (Cambrea et al., 2017). Keberadaan dewan komisaris asing dianggap dapat memberikan dampak positif dalam meningkatkan mekanisme pengawasan terhadap perusahaan karena dewan komisaris asing merupakan komisaris yang independen dan cenderung memiliki konflik yang lebih kecil. Keberadaan dewan komisaris asing yang memiliki pengalaman yang lebih baik tentang operasi perusahaan dapat memberikan nilai tambah bagi perusahaan (Reese dan Weisbach, 2002). Semua keputusan yang diambil harus mempunyai persetujuan terlebih dahulu kepada komisaris. Adanya komisaris asing akan membuat perusahaan mempunyai pengetahuan yang terbaik dalam keputusan kebijakan pendanaan yang harus dilakukan ketika pendanaan yang diperoleh dari internal perusahaan tidak mencukupi untuk pelaksanaan kegiatan operasional perusahaan.

Kenaikan jumlah Tenaga Kerja Asing yang menduduki tingkat jabatan direksi yang terus meningkat, mengindikasikan bahwa Direksi Asing dapat membantu mengelola perusahaan yang ada di Indonesia lebih baik dengan opini dan perspektif yang beragam dari berbagai kebiasaan seperti budaya kehidupan dari tempat negara mereka berasal. Menurut Ararat (2010) berpendapat bahwa anggota dewan asing dapat membawa opini dan pandangan baru yang bermacam-macam seperti bahasa, agama, pengalaman pendidikan, budaya kehidupan dan profesionalitas yang berbeda dari satu negara ke negara lain.

Keberadaan direksi asing diharapkan akan memberikan nilai tambah bagi perusahaan karena mereka memberikan masukan, pengalaman dan ide yang lebih beragam (Setiawan et al., 2018).

TINJAUAN TEORETIS Pecking Order Theory 
Teori ini dikemukakan oleh (Myers dan Maljuf, 1984). Penelitian Mayangsari (2001) menyatakan bahwa pecking order theory cenderung memilih pendanaan sesuai dengan urutan risiko, yaitu laba ditahan, utang, dan terakhir penerbitan ekuitas. Teori ini menjelaskan mengenai pemilihan sumber pendanaan yang membandingkan antara sumber pendanaan internal dan eksternal. Dana internal lebih disukai daripada pendanaan eksternal karena pendanaan internal memberikan perusahaan kesempatan untuk tidak membuka diri dari pemodal luar (Firnanti, 2011).

Pecking order theory menyatakan bahwa perusahaan yang profitable (menguntungkan) cenderung menggunakan pinjaman dalam jumlah sedikit, dikarenakan memerlukan pembiayaan eksternal yang sedikit bukan karena perusahaan mempunyai target rasio utang yang rendah. Malah sebaliknya, perusahaan yang kurang profitable cenderung mempunyai utang yang lebih besar karena dana internal perusahaan tidak cukup dan utang merupakan sumber dana eksternal yang lebih disukai (Oktaviani, 2017).

Perusahaan ketika memilih dana internal untuk mendanai kegiatan operasionalnya dengan laba ditahan yang diinvestasikan kembali. Tetapi jika diperlukan pendanaan eksternal, lebih memilih menggunakan utang. Penerbitan utang mempunyai dampak kecil pada harga saham. Perusahaan menyukai pendanaan internal karena dana ini terkumpul tanpa mengirimkan sinyal sebaliknya yang dapat menurunkan harga saham. Jika dana eksternal dibutuhkan, perusahaan menerbitkan utang lebih dahulu dan hanya menerbitkan ekuitas sebagai pilihan terakhir (Lessy, 2016). Penggunaan dana internal lebih disukai karena memungkinkan perusahaan untuk tidak membuka peluang dalam memperoleh pendanaan dari luar perusahaan.

Dana eksternal lebih disukai dalam bentuk utang daripada modal sendiri karena dua alasan. Pertama adalah pertimbangan biaya penerbitan obligasi lebih murah dari biaya penerbitan saham baru (Sugiarto, 2009). Kedua, manajer khawatir jika penerbitan saham baru akan diartikan sebagai kabar buruk oleh para investor atau kreditur dan membuat harga saham menjadi turun, hal ini disebabkan adanya asimetri informasi antara pihak manajemen dan investor sehingga setiap perilaku manajer sering kali dijadikan sinyal mengenai kondisi dan prospek perusahaan dimasa depan. Menurut teori struktur modal, konsep pecking oreder theory lebih mengandalkan pengambilan keputusan pendanaan sesuai dengan urutan yaitu dari internal berupa laba ditahan kemudian pendanaan eksternal yaitu utang dan terkahir penerbitan saham.

\section{Teori Agensi (Agency Theory)}

Teori keagenan membahas mengenai hubungan keagenan yang membahas suatu kontrak antara pemilik perusahaan yang menggunakan jasa orang lain atau agen dalam menjalankan aktivitas perusahaan. Konflik kepentingan dapat mendasari orang bertindak untuk memenuhi kepentingannya terlebih dahulu sebelum memenuhi kebutuhan orang lain.

Teori keagenan menjelaskan hubungan antara agen (agen yang mengatur manajemen sebuah usaha) dan principal (pemilik usaha). Pemilik usaha disebut sebagai pihak yang melakukan evaluasi terhadap informasi yang disajikan oleh agen yang bertindak sebagai pihak yang mengambil keputusan (Septiani, 2005). Manajer merupakan pihak yang dikontrak oleh pemegang saham untuk bekerja demi kepentingan pemegang saham. Untuk itu manajemen diberikan kekuasaan untuk membuat keputusan bagi kepentingan terbaik pemegang saham. Oleh karena itu manajemen wajib mempertahankan tanggungjawab semua upayanya kepada pemegang saham (Apriada, 2013)

Agency theory mengasumsikan bahwa masing-masing individu termotivasi oleh kepentingan dirinya sendiri sehingga dapat menyebabkan agency conflict antara principal 
dan agent. Pihak principal mempunyai kepentingan untuk meningkatkan kemakmuran perusahaannya dengan cara mengadakan kontrak dengan agent, sedangkan agent cenderung berperilaku oportunis dan berorientasi pada pemenuhan kepentingan pribadi dengan mengorbankan kepentingan principal (Nikmah dan Arifianto, 2013). Menurut Jensen dan Meckling (1976) menjelaskan bahwa pemisahan antara kepemilikan dan pengelolaan perusahaan akan selalu diikuti oleh munculnya agency cost akibat tidak sinkronnya kepentingan antara pemilik dan pengelola.

Manajemen diharapkan dalam mengambil kebijakan perusahaan terutama kebijakan keuangan, dapat memberikan keuntungan bagi pemilik perusahaan. Bila keputusan manajemen merugikan bagi pemilik perusahaan, maka dapat memicu adanya agency problem. Hal tersebut dapat diminimalisir dengan agency cost (biaya agensi). Agency cost merupakan pemberian insentif yang layak kepada manajer serta biaya pengawasan untuk mencegah moral hazard. Hubungan keagenan akan menimbulkan cost bagi prinsipal, seperti pengeluaran atas pengawasan tindakan agent dan pengeluaran atas adanya perikatan kontrak dengan agen. Untuk mencegah terjadinya konflik keagenan dan mengurangi asimetri informasi, maka sudah menjadi kewajiban bagi pihak manajemen untuk melaporkan laporan keuangan secara tepat waktu.

Menurut Alijoyo dan Zaini (2004) mengasumsikan beberapa dasar yang membangun agency theory, yaitu:

1. Agency conflict

Adanya kemungkinan konflik yang terjadi dalam hubungan antara prinsipal dan agen yang timbul sebagai akibat keinginan manajemen (agent) untuk melakukan tindakan yang sesuai dengan kepentingannya yang dapat mengorbankan kepentingan pemegang saham untuk memperoleh return dan nilai jangka panjang perusahaan. Halhal yang sering timbul pada konflik agensi ini yaitu: a. Moral Hazard

Manajemen memilih investasi yang paling sesuai dengan kemampuan dirinya dan bukan yang paling menguntungkan bagi perusahaan.

b. Earning Retention

Manajemen cenderung mempertahankan tingkat pendapatan perusahaan yang stabil, sedangakan pemegang saham lebih menyukai distribusi kas yang lebih tinggi melalui beberapa peluang investasi internal yang positif.

c. Time Horizon

Manajemen cenderung hanya memperhatikan cash flow perusahaan sejalan dengan waktu penugasan mereka. Hal seperti ini dapat menimbulkan bias dalam pengambilan keputusan yang berpihak pada proyek jangka pendek dengan pengembalian yang tinggi dan kurang berpihak pada proyek jangka panjang dengan pengembalian NPV positif yang jauh lebih besar.

\section{Agency Problem}

Agency problem merupakan permasalahan yang timbul sebagai akibat adanya kesenjangan antara kepentingan pemegang saham sebagai pemilik dan manajemen sebagai pengelola. Pemilik memiliki kepentingan terhadap perolehan insentif atas pengelolaan dana pemilik.

Jensen dan Meckling (1976) yang dapat dilakukan untuk mengurangi kesempatan manajer melakukan tindakan yang merugikan investor luar, ada dua cara yaitu investor luar melakukan pengawasan (monitoring) dan manajer sendiri melakukan pembatasan atas tindakannya (bonding). Kegiatan tersebut akan mengurangi kesempatan penyimpangan oleh manajer sehingga nilai perusahaan akan meningkat. Namun disisi lain, keduanya akan memunculkan biaya sehingga akan mengurangi nilai perusahaan. Mekanisme monitoring dapat dilakukan dengan pembentukan Dewan komisaris, pasar corporate control, pemegang saham besar, kepemilikan terkonsentrasi, dan pasar manajemen. Mekanisme kontrol dilakukan dengan peningkatan kepemilikan manajer 
dan bonding dengan meningkatkan utang dan meningkatkan deviden (Arifin dan Rachmawati, 2006 dalam Aryati, 2012).

\section{Modal dan Struktur Modal}

Sebuah perusahaan, selisih antara aset dan kewajiban disebut sebagai modal pemegang saham atau ekuitas pemilik. Terdapat perbedaan antara modal yang berasal dari investasi pemegang saham yang disebut modal kontribusi atau modal disetor (paid in capital) dan modal yang berasal dari laba disebut sebagai laba ditahan atau saldo laba (retained earning). Modal kontribusi dalam neraca disajikan ke dalam dua bagian yaitu modal saham dan tambahan modal disetor.

Modal saham adalah jumlah lembar saham yang diterbitkan di kali nilai nominal, sedangkan tambahan modal disetor merupakan investasi pemegang saham dari pembayaran yang melebihi nilai nominal. Modal yang berasal dari laba ditahan adalah jumlah laba perusahaan yang tidak dibagikan kepada pemegang saham.

Struktur modal adalah perbandingan antara sumber jangka panjang yang bersifat pinjaman dan modal sendiri (Husnan, 2000). Untuk mencapai tujuan perusahaan dalam memaksimilisasi kekayaan pemegang saham, manajer keuangan harus dapat menilai struktur modal dan memahami hubungannya dengan risiko, hasil atau pengembalian nilai. Target dari struktur modal adalah menciptakan suatu komposisi dari utang dan modal usaha yang paling tepat dan paling menguntungkan dari segi utang dan modal usaha yang paling tepat dan paling me- nguntungkan dari segi keuangan

Struktur modal berkenaan dengan bagaimana modal dialokasikan dalam aktivitas investasi aset riil perusahaan, dengan cara menentukan struktur modal antara modal asing dan modal sendiri. Tugas manajemen keuangan adalah menentukan struktur modal optimal untuk menunjang kegiatan investasi perusahaan (Harmono, 2009).

Struktur modal berkaitan dengan sumber dana, baik yang berasal dari internal maupun eksternal perusahaan. Sumber dana internal berasal dari dana yang terkumpul dari laba yang ditahan yang berasal dari kegiatan perusahaan. Sedangkan sumber dana eksternal berasal dari pemilik yang merupakan komponen modal sendiri dan dana yang berasal dari para kreditur yang merupakan modal pinjaman atau utang. Penentuan struktur modal merupakan kebijakan yang diambil oleh pihak manajemen dalam rangka memperoleh sumber dana sehingga dapat digunakan untuk aktivitas operasional perusahaan (Nugroho, 2006).

Struktur modal merupakan masalah penting yang dihadapi bagi perusahaan kerena baik buruknya struktur modal dapat mempengaruhi secara langsung terhadap posisi keuangan perusahaan yang akhirnya dapat berdampak tehadap nilai perusahaan sehingga ketika menentukan struktur modal terjadi kesalahan maka dapat meningkatkan dampak risiko finansial yang harus ditanggung oleh perusahaan (Kesuma, 2009). Struktur modal yang optimal merupakan suatu kondisi dimana perusahaan dapat menggunakan utang dan ekuitas secara ideal dari menyeimbangkan antara nilai perusahaan dan biaya atas struktur modalnya. Perubahan struktur modal dapat terjadi setiap waktu yang dapat mempengaruhi biaya nodal tertimbang sehingga akan berpengaruh terhadap keputusan anggaran modal dan akhirnya dapat berpengaruh terhadap harga saham perusahaan (Firnanti, 2011).

Perusahaan memerlukan dana yang berasal dari modal sendiri dan modal asing. Penerapan struktur modal perusahaan perlu mempertimbangkan berbagai variabel yang memengaruhinya. Faktor-faktor yang berpengaruh terhadap struktur modal antara lain: stabilitas penjualan, struktur aset, leverage operasi, tingkat pertumbuhan, profitabilitas, pajak, kendali, sikap manajemen, sikap pemberi pinjaman dan lembaga pemeringkat, kondisi pasar, kondisi internal perusahaan, dan fleksibilitas keuangan.

Keputusan pendanaan suatu perusahaan adalah keputusan yang harus dilakukan oleh manajer keuangan yang berkaitan 
dengan dimana dana perusahaan dipenuhi, berkaitan dengan analisis biaya dana atau modal yang digunakan perusahaan (Wiagustini, 2010). Menurut Riyanto (2011), pemenuhan dana perusahaan dapat berasal dari sumber internal dan sumber eksternal. Kebutuhan dana perusahaan dari sumber internal, yaitu sumber dana yang dibentuk atau dihasilkan sendiri didalam perusahaan, biasanya berupa laba ditahan dan depresiasi. Kebutuhan dana perusahaan dapat pula berasal dari eksternal, yaitu sumber dana dari luar perusahaan yang berasal dari para kreditur dan pemilik, peserta atau pengambil bagian di dalam perusahaan.

Besarnya utang yang digunakan oleh perusahaan adalah suatu kebijakan yang berhubungan dengan struktur modal. Kebijakan utang merupakan penentuan berapa besarnya utang akan digunakan perusahaan dalam mendanai aktivanya yang ditunjukkan oleh rasio antara total utang dengan total aktiva. Kebijakan utang termasuk pendanaan perusahaan yang bersumber dari eksternal (Hartono, 2016).

\section{Komisaris dan Komisaris Asing}

Dewan komisaris merupakan salah satu bagian dari konsep corporate governance yang diharapan dapat memberikan keyakinan kepada para stakeholder terutama kepada investor. Dewan Komisaris sebagai organ perusahaan bertugas dan bertanggungjawab secara kolektif untuk melakukan pengawasan dan memberikan nasihat kepada Direksi serta memastikan bahwa Perusahaan melaksanakan GCG. Namun demikian, Dewan Komisaris tidak boleh turut serta dalam mengambil keputusan operasional. Kedudukan masing-masing anggota Dewan Komisaris termasuk Komisaris Utama adalah setara. Tugas Komisaris Utama adalah mengkoordinasikan kegiatan Dewan Komisaris, maka, pelaksanaan tugas Dewan Komisaris dapat berjalan secara efektif, maka wajib memenuhi prinsip-prinsip berikut: 1. Komposisi Dewan Komisaris harus memungkinkan pengambilan keputusan secara efektif, tepat dan cepat, serta dapat bertindak independen, 2. Anggota Dewan Komisaris harus profesional, yaitu berintegritas dan memiliki kemampuan sehingga dapat menjalankan fungsinya dengan baik termasuk memastikan bahwa Direksi telah memperhatikan kepentingan semua pemangku kepentingan, 3. Fungsi pengawasan dan pemberian nasihat Dewan Komisaris mencakup tindakan pencegahan, perbaikan, sampai kepada pemberhentian sementara.

Dewan komisaris memiliki peran untuk mengawasi praktik usaha yang dilakukan perusahaan (Triani, 2018). Menurut UU PT No. 40 Pasal 1 ayat 6, dewan komisaris bertugas melakukan pengawasan atas kebijakan pengurusan perusahaan. Fungsi utama dewan komisaris adalah mengawasi kelengkapan dan kualitas informasi laporan atas kinerja dewan direksi. Sesuai dengan asas tata kelola perusahaan yaitu kesetaraan dan kewajaran, menyatakan bahwa karyawan di dalam suatu perusahaan diperlakukan sama tanpa melihat ras, jenis kelamin, kebangsaan dan kondisi fisik.

Tugas-tugas utama Dewan Komisaris meliputi: a. Menilai dan mengarahkan strategi perusahaan, menentukan startegi untuk rencana kerja yang akan dicapai, kebijakan pengendalian risiko, anggaran tahunan, menetapkan tujuan perusahaan, mengawasi pelaksanaan dan kinerja perusahaan, serta melakukan pengawasan atas penggunaan modal perusahaan dan atas investasi dan penjualan asset perusahaan, $b$. Menilai sistem penetapan penggajian pejabat pada posisi atas dan penggajian anggota Dewan Direksi, serta menjamin suatu proses pencalonan anggota Dewan Direksi bersifat transparan dan adil, c. Melakukan pengawasan dan mengatasi masalah jika terjadi perbedaan kepentingan pada tingkat manajemen, anggota Dewan Direksi dan anggota Dewan Komisaris, termasuk penyalahgunaan aset perusahaan dan manipulasi transaksi perusahaan.

Dewan Komisaris tidak boleh ikut dalam proses pengambilan keputusan operasional perusahaan. Kedudukan antara 
anggota Dewan Komisaris dan Komisaris Utama adalah sejajar (KNKG, 2006). Menurut Undang-Undang Perseroan Terbatas Nomor 40 tahun 2007, pada pasal 108 ayat 5 dijelaskan bahwa bagi perusahaan berbentuk perseroan terbatas, maka wajib memiliki paling sedikitnya dua anggota Dewan Komisaris. Oleh karena itu, jumlah anggota dewan komisaris disesuaikan dengan kompleksitas setiap perusahaan dengan tetap memfokuskan efektivitas dalam proses pengambilan keputusan.

Dewan komisaris terdiri dari dua jenis yaitu Komisaris yang terafiliasi dan tidak dari terafiliasi yang disebut sebagai Komisaris Independen. Pihak terafiliasi adalah pihak yang mempunyai hubungan bisnis dan kekeluargaan dengan para pemangku kepentingan yaitu pemegang saham pengendali, anggota Direksi, dan Dewan Komisaris lainnya.

Dalam tugasnya dewan komisaris dibantu oleh empat komite penunjang yaitu komite audit, komine nominasi dan remunerasi, komite kebijakan resiko, dan komite kebijakan corporate governance (KNKG, 2006). Komite Audit bertugas membantu Dewan Komisaris untuk memastikan bahwa laporan keuangan yang dibuat oleh manajer disajikan dengan wajar sesuai dengan prinsip akuntansi yang berlaku umum, melaksanakan struktur pengendalian internal perusahaan dengan baik, pelaksanaan audit internal maupun eksternal dilakukan sesuai standar audit yang berlaku, dan tindak lanjut temuan hasil audit.

Calon auditor eksternal harus melalui proses dari Komite Audit untuk disampaikan kepada Dewan Komisaris. Jumlah anggota Komite Audit harus sesuai dengan kompleksitas perusahaan dengan tetap memperhatikan efektifitas dalam proses pengambilan keputusan. Bagi perusahaan yang sahamnya tercatat di bursa efek, perusahaan negara, perusahaan daerah, perusahaan yang menghimpun dan mengelola dana masyarakat, perusahaan yang produk atau jasanya digunakan oleh masya- rakat luas, serta perusahaan yang mempunyai dampak luas terhadap kelestarian lingkungan, Komite Audit diketuai oleh Komisaris Independen dan anggotanya dapat terdiri dari Komisaris dan atau profesi dari luar perusahaan. Salah seorang anggota harus memiliki latar belakang dan kemampuan akuntasi dan atau keuangan.

Komite Nominasi dan Remunerasi bertugas membantu Dewan Komisaris dalam menentukn kriteria pemilihan calon anggota Dewan Komisaris dan Direksi serta sistem remunerasinya. Dewan Komisaris dapat mengajukan calon tersebut dan remunerasinya untuk memperoleh keputusan RUPS dengan cara sesuai ketentuan Anggaran Dasar. Komite Nominasi dan Remunerasi diketuai oleh Komisaris Independen dan anggotanya dapat terdiri dari Komisaris dan atau pelaku profesi dari eksternal perusahaan dan hasil laporan kerja dalam RUPS.

Komite Kebijakan Risiko mempunyai tugas yaitu membantu Dewan Komisaris dalam sistem manajemen risiko yang disusun oleh Direksi serta menilai risiko yang dapat ditoleransi oleh perusahaan dan anggotanya terdiri dari anggota Dewan Komisaris, namun jika diperlukan dapat menunjuk para pelaku profesi dari luar perusahaan.

Komite Kebijakan Corporate Governance bertugas membantu Dewan Komisaris dalam mengkaji kebijakan GCG secara menyeluruh yang disusun oleh Direksi serta menilai konsistensi penerapannya, termasuk yang berhubungan dengan etika bisnis dan tanggung jawab sosial perusahaan (corporate social responsibility) dan anggotanya terdiri dari anggota Dewan Komisaris, dan juga bisa berasal dari luar perusahaan misalnya pelaku profesi. Komisaris asing yang diyakini memiliki pengetahuan yang berbeda dari setiap negara berasal. Komisaris asing merupakan komisaris bersifat independen dan memiliki sedikit konflik sehingga komisaris asing akan memberikan keputusan yang sesuai dengan budaya di setiap negara. Sesuai dengan Peraturan Otoritas 
Jasa Keuangan Nomor 30/POJK.05/2014 Tentang Tata Kelola Perusahaan yang Baik Bagi Perusahaan Pembiayaan Pasal 18 poin 3 menyatakan bahwa anggota Dewan Komisaris berkewarganegaraan asing yang berdomisili di Indonesia harus memiliki surat izin menetap dan surat izin bekerja dari instansi berwenang.

\section{Pengaruh Komisaris Asing Terhadap Struktur Modal}

Komisaris asing yang direkrut oleh perusahaan diyakini memiliki pengalaman, latar belakang teknis serta kompetensi yang berbeda dengan komisaris domestik. Masuknya dewan komisaris asing akan meningkatkan mekanisme pengawasan perusahaan karena dewan komisaris asing pada umumnya adalah komisaris bersifat independen dan memiliki sedikit konflik. Keberadaan dewan komisaris asing dapat memberikan pengalaman yang lebik baik karena pengetahuan yang lebih banyak dari berbagai negara sehingga akan menambah nilai untuk perusahaan (Reese dan Weisbach, 2002). Adanya keberadaan komisaris asing dianggap dapat meningkatkan kemampuan manajerial untuk menjadi lebih baik sehingga dapat memberikan nilai yang lebih tinggi dan dapat berdampak positif terhadap kinerja perusahaan (Nikmah dan Arifianto, 2013;

Pradono dan Widowati, (2016). Perusahaan dapat memanfaatkan pengetahuan dari komisaris untuk memilih kebijakan utang yang sesuai dengan tujuan perusahaan.

$\mathrm{H}_{1}$ : Komisaris Asing Berpengaruh Positif Terhadap Struktur Modal

\section{Direksi dan Direksi Asing}

Direksi sesuai dengan KNKG (2006) sebagai organ perusahaan bertugas dan bertanggungjawab secara kolegial dalam mengelola perusahaan. Masing-masing anggota Direksi dapat melaksanakan tugas dan mengambil keputusan sesuai dengan pembagian tugas dan wewenangnya. Namun, pelaksanaan tugas oleh masing-masing anggota Direksi tetap merupakan tanggung jawab bersama. Kedudukan masing-masing anggota Direksi termasuk Direktur Utama adalah setara. Tugas Direktur Utama sebagai primus inter pares adalah mengkoordinasikan kegiatan Direksi.

Agar pelaksanaan tugas Direksi dapat berjalan secara efektif, perlu dipenuhi prinsip-prinsip berikut: 1. Komposisi Direksi harus sedemikian rupa sehingga memungkinkan pengambilan keputusan secara efektif, tepat dan cepat, serta dapat bertindak independen, 2. Direksi harus profesional yaitu berintegritas dan memiliki pengalaman serta kecakapan yang diperlukan untuk menjalankan tugasnya, 3. Direksi bertanggung jawab terhadap pengelolaan perusahaan agar dapat menghasilkan keuntungan (profitability) dan memastikan kesinambungan usaha perusahaan, 4. Direksi mempertanggungjawabkan kepengurusannya dalam RUPS sesuai dengan peraturan perundang-undangan yang berlaku.

Menuurt UU No. 40 tahun 2007 tentang perseroan terbatas adalah bahwa direksi merupakan organ perseroan yang berwenang dan bertanggung jawab atas pengurus perseroan untuk kepentingan perseroan, sesuai dengan maksud dan tujuan perseroan serta mewakili perseroan baik dalam maupun di luar pengadilan sesuai dengan ketentuan anggaran dasar.

Tugas dan tanggungjawab direksi adalah sebagai suatu organ yang merupakan tanggung jawab sesama anggota dewan direksi terhadap perseroan. Direksi tidak secara sendiri-sendiri bertanggung jawab kepada perseroan. Ini membutikkan bahwa setiap tindakan yang diambil atau dilakukan oleh suatu satu atau lebih anggota direksi akan mengikat anggota direksi lainnya. Dewan direksi bertanggung jawab penuh atas manajemen perusahaan. Setiap anggota direksi bertanggung jawab penuh dan secara pribadi jika bersalah atau lalai dalam menjalankan tugas-tugasnya. Dewan direksi diharuskan menjalankan setiap tugas dan tanggung jawabnya sesuai dengan UndangUndang Perseroan Terbatas yang bertujuan 
untuk kepentingan perusahaan. Sesuai dengan KNKG (2006) dewan direksi mempunyai tanggungjawab terhadap perusahaan antara lain yaitu Direksi wajib menyusun pertanggungjawaban pengelolaan perusahaan dalam bentuk laporan tahunan yang memuat antara lain laporan keuangan, laporan kegiatan perusahaan, dan laporan pelaksanaan GCG, laporan tahunan harus memperoleh persetujuan RUPS, dan khusus untuk laporan keuangan harus memperoleh pengesahan RUPS, laporan tahunan harus telah tersedia sebelum RUPS diselenggarakan sesuai dengan ketentuan yang berlaku untuk memungkinkan pemegang saham melakukan penilaian.

Peraturan Otoritas Jasa Keuangan Nomor 33/POJK.04/2014 Tentang Direksi Dan Dewan Komisaris Emiten Atau Perusahaan Publik Pasal 3 poin 1 bahwa Dewan Direksi diangkat dan diberhentikan oleh RUPS dan pasal 6 poin c menyatakan bahwa anggota komite paling banyak lima komite di Emiten atau perusahaan Publik yang juga menjabat sebagai anggota Direksi atau anggota Dewan Komisaris. Adanya penanaman modal asing, maka pemilik modal biasanya juga akan merekomendasikan anggota dewan yang juga berkewarganegaraan asing (Choi et al., 2012). Melalui anggota dewan, investor asing dapat melakukan pengawasan dan memastikan bahwa kepentingan mereka terlindungi dengan adanya diversitas dalam anggota dewan (Swartz dan Firer, 2005). Penelitian Gulamhussen dan Guerreiro (2009) menyatakan dalam penelitiannya bahwa anggota dewan berkewarganegaraan asing dapat membawa ide, gagasan pengetahuan dan keahlian baru untuk membantu meningkatkan efektivitas dan efisiensi operasional perusahaan meskipun perusahaan harus mengeluarkan biaya yang cukup besar untuk mempekerjakan mereka. Sesuai dengan Peraturan Otoritas Jasa Keuangan Nomor 30/POJK.05/2014 Tentang Tata Kelola Perusahaan yang Baik Bagi Perusahaan Pembiayaan Pasal 8 poin 6 menyatakan bahwa anggota Direksi berkewarganegaraan asing harus memiliki surat izin menetap dan surat izin bekerja dari instansi berwenang.

\section{Pengaruh Direksi Asing Terhadap Struktur Modal}

Direksi mempunyai tugas untuk mengelola kegiatan perusahaan salah satunya adalah mempunyai wewenang dalam proses pengambilan keputusan. Adanya direksi asing maka dapat meningkatkan kemampuan dan keahlian yang dimiliki oleh dewan direksi karena adanya keahlian dan pengalaman yang baru (Polovina dan Peasnell, 2015). Pernyatan tersebut didukung penelitian (Gulamhussen dan Guerreiro, 2009) yang menemukan bahwa anggota dewan direksi yang berkewarganegaraan asing mempunyai pengaruh positif terhadap pengurangan biaya operasional karena direksi asing dapat membawa ide, gagasan, pengetahuan dan keahlian baru dapat memberikan kontribusi untuk meningkatkan efektivitas organisasi dan efisiensi operasional perusahaan. Keahlian ilmu pengetahuan yang dimiliki direksi asing dapat dimanfaatkan sebuah perusahaan pada saat mengimplementasikan pergerakan ekspansinya dari berbagai macam pangsa pasar yang strategis (Saragih, 2019). Menurut (Ujunwa, 2012) dalam penelitiannya, menemukan bahwa direksi asing berpengaruh positif signifikan terhadap kinerja finansial karena kemampuan dalam memonitor dan memiliki informasi yang lebih baik. Penemuan tersebut serupa dengan penelitian (Choi et al., 2012), yang menyatakan bahwa Direksi Asing memiliki kemampuan yang lebih dalam hal manajerial.

$\mathrm{H}_{2}$ : Direksi Asing berpengaruh positif terhadap Struktur Modal

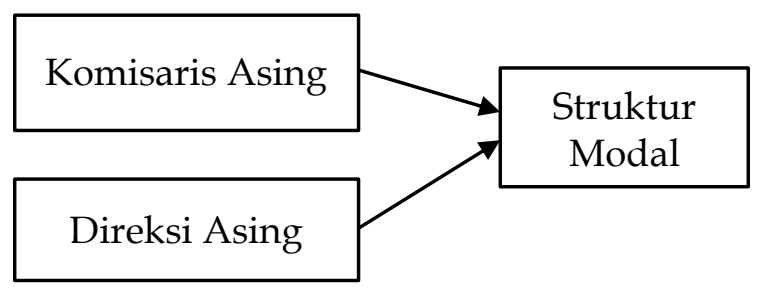

Gambar 1 Rerangka konseptual 


\section{METODE PENELITIAN}

Jenis Penelitian dan Gambaran dari Populasi (Objek) Penelitian

Penelitian ini menggunakan data sekunder, yaitu data yang diperoleh dari laporan keuangan perusahaan manufaktur yang diteliti. Jenis data yang digunakan dalam penelitian ini adalah data kuantitatif. Populai (obyek) yang digunakan dalam penelitian ini merupakan Perusahaan Manufaktur yang terdaftar di Bursa Efek Indonesia Periode 2012-2018.

\section{Teknik Pengambilan Sampel}

Penentuan sampel pada penelitian ini menggunakan metode purposive sampling. Perusahaan yang digunakan adalah Perusahaan Manufaktur yang terdaftar di Bursa Efek Indonesia periode tahun 2012-2018.

\section{Teknik Pengumpulan Data}

Data yang digunakan dalam penelitian ini adalah data sekunder. Metode pengumpulan data yang digunakan yaitu metode studi pustaka dan mengkaji data sekunder, berupa laporan keuangan Perusahaan Manufaktur yang terdaftar di BEI tahun 2012-2018.

\section{Variabel dan Pengukuran Variabel Dependen}

Variabel dependen dalam penelitian ini adalah sruktur modal. Struktur modal merupakan penggunaan total utang terhadap modal sendiri, Pengukuran yang digunakan dalam penelitian ini adalah dengan menggunakan pengukuran Debt Equity Ratio (Prasetia et al., 2014). Debt Equity Ratio merupakan perbandingan antara jumlah utang dapat berupa utang jangka pendek atau disebut dengan utang lancar dan utang jangka panjang terhadap total modal sendiri, total modal sendiri dapat berupa modal saham dan laba yang ditahan (Kurnia, 2017). Rumus perhitungannya adalah:

$$
\text { Debt Equity Ratio }=\frac{\text { Jumlah Utang }}{\text { Total Ekuitas }}
$$

\section{Variabel Independen}

Komisaris Asing

Dewan komisaris merupakan salah satu organ perusahaan yang penting dalam menjalankan GCG. Dewan Komisaris berfungsi sebagai pengawas dan pemberi nasihat pada perusahaan (Saragih, 2019).

Rumus perhitungannya adalah:

Komisaris Asing $=\frac{\text { Jumlah Komisaris Asing }}{\text { Jumlah Komisaris }}$

\section{Direksi Asing}

Dewan Direksi juga merupakan salah satu bagian dari perusahaan yang penting dalam menjalankan GCG. Sebagai bagian dari perusahaan, Direksi bertugas untuk mengelola aktivitas perusahaan. Direksi bertugas dalam mengambil keputusan sesuai dengan wewenangnya (Saragih, 2019). Direksi Asing dalam penelitian ini diukur dari persentase direksi yang berkewarganegaraan asing terhadap jumlah anggota direksi (Toyyibah, 2012).

Rumus perhitungannya adalah:

Direksi Asing $=\frac{\text { Jumlah Direksi Asing }}{\text { Jumlah Direksi }}$

\section{Variabel Kontrol}

Variabel kontrol dalam penelitian ini adalah Pertumbuhan Penjualan (Growth), Effective Tax Rate (ETR), Dividend Payout Ratio (DPR), Kepemilikan Manajerial (KM), dan Kepemilikan Institusional (KI). Pertumbuhan penjualan mengakibatkan perusahaan memerlukan penanaman modal untuk mendukung kegiatan operasional dalam mewujudkan perkembangan perusahaan. ketika pertumbuhan penjualan mengalami peningkatan menunjukkan bahwa semakin banyak pendanaan yang diperlukan salah satunya berasal dari pendanaan dalam bentuk utang. Penelitian ini menggunakan Pertumbuhan Penjualan (Growth) sebagai variabel kontrol Rumus perhitungannya adalah:

$$
\text { Growth }=\frac{\text { Penjualan }_{(\mathrm{t})}-\text { Penjualan }_{(\mathrm{t}-1)}}{\text { Penjualan }_{(\mathrm{t}-1)}}
$$


Penggunaan utang yang tinggi oleh perusahaan digunakan untuk mengurangi besarnya pajak yang harus dibayar perusahaan, sehingga penelitian ini menggunakan Effective Tax Rate (ETR) sebagai variabel kontrol. Rumus perhitungannya adalah:

$$
\text { Effective Tax Rate }=\frac{\text { Beban Pajak Penghasilan }}{\text { Laba sebelum pajak }}
$$

Kebijakan dividen menunjukkan bahwa ketika perusahaan mendapat keuntungan akan membagikan pendapatan sebagai dividen kepada investor sehingga investor akan menunjukkan respon yang positif terhadap perusahaan. Penelitian ini menggunakan Dividend Payout Ratio sebagai variabel kontrol. Rumus perhitungannya adalah:

$$
D P R=\frac{\text { DPS }}{\text { EPS }}
$$

Keterangan:

DPR $=$ Dividend Payout Ratio

DPS $=$ Dividend per lembar saham

$E P S=$ Earnings per lembar saham

Kepemilikan manajerial menunjukkan bahwa manajer merasakan dampak ketika manajer mengambil keputusan. Kepemilikan manajerial akan berpengaruh terhadap struktur modal. Ketika manajer memiliki saham di perusahan maka perusahaan akan cenderung untuk menerapkan kebijakan utang yang lebih sedikit. Penelitian ini menggunakan Kepemilikan Manajerial sebagai variabel kontrol. Rumus perhitungannya adalah:

Keterangan:

$$
\mathrm{KM}=\frac{\text { Jumlah Saham Manajerial }}{\text { Jumlah Saham yang beredar }}
$$

KM: Kepemilikan Manajerial

Kepemilikan institusional didalam perusahaan sangat penting sebagai pengawasan untuk setiap keputusan yang diambil oleh perusahaan. Kepemilikan institusional akan bertindak untuk mengawasi sikap manajemen dalam menggunakan utang per- usahaan. Penelitian ini menggunakan Kepemilikan Institusional sebagai variabel kontrol. Rumus perhitungannya adalah:

$$
\mathrm{KI}=\frac{\text { Jumlah Saham Institusional }}{\text { Jumlah Saham yang beredar }}
$$

Keterangan:

KM: Kepemilikan Institusional

\section{Model Analisis}

Analisis yang digunakan dalam penelitian ini adalah regresi linier berganda dengan model regresi sebagai berikut:

$$
\begin{aligned}
\text { DER }= & a+\beta 1 \mathrm{KA}+\beta 2 \mathrm{DA}+\beta 3 \text { Growth }+ \\
& \beta 4 \mathrm{ETR}+\beta 5 \mathrm{DPR}+\beta 6 \mathrm{KM}+\beta 7 \mathrm{KI}+ \\
& \varepsilon
\end{aligned}
$$

Dimana:

$\begin{array}{ll}\text { DER } & \text { : Debt Equity Ratio } \\ \text { a } & \text { : konstansta } \\ \text { KA } & \text { : Dewan Komisaris Asing } \\ \text { DA } & \text { : Dewan Direksi Asing } \\ \text { GROWTH } & \text { : Pertumbuhan Penjualan } \\ \text { ETR } & \text { : Effective Tax Rate } \\ \text { DPR } & : \text { Dividend Payout Ratio } \\ \text { KM } & \text { : Kepemilikan Manajerial } \\ \text { KI } & : \text { Kepemilikan Institusional } \\ \varepsilon & : \text { error }\end{array}$

\section{ANALISIS DAN PEMBAHASAN Analisis Statistik Deskriptif}

Analisis statistik deskriptif bertujuan untuk mengetahui gambaran umum terhadap obyek yang diteliti untuk mendeskripsikan suatu data yang menunjukkan hasil pengukuran dari rata-rata (mean), standar deviasi dan maksimum-minimum (Ghozali, 2013). Data yang digunakan dalam penelitian ini adalah berupa annual report perusahaan manufaktur yang terdatar di Bursa Efek Indonesia pada periode tahun 2012-2018 sebanyak 31 perusahaan yang diolah menggunakan SPSS versi 25. Hasil yang terdiri dari statistik deskriptif, uji asumsi klasik, dan uji regresi. Hasil analisis statistik deskriptif dengan menggunakan program SPSS 25 adalah sebagai berikut: 
Tabel 1

Analisis Statistik Deskriptif

\begin{tabular}{lccccc}
\hline \hline & $\mathbf{N}$ & Minimum & Maximum & Mean & Std. Deviation \\
\hline DER & 31 & .150 & 2.137 & .617 & .509 \\
KA & 31 & .200 & .700 & .514 & .136 \\
DA & 31 & .090 & .642 & .411 & .187 \\
Growth & 31 & -.086 & .244 & .078 & .082 \\
ETR & 31 & .066 & .539 & .256 & .084 \\
DPR & 31 & .075 & 2.222 & .482 & .483 \\
KM & 31 & .000 & .150 & .005 & .026 \\
KI & 31 & .501 & .866 & .693 & .144 \\
Valid N (listwise) & 31 & & & & \\
\hline
\end{tabular}

Sumber: Data telah diolah

Berdasarkan statistik deskriptif variabel penelitian yang disajikan dalam Tabel 1 tersebut, maka dapat diinterpretasi sebagai berikut: a). Jumlah pengamatan (n) yang diteliti yaitu sebanyak 31 pengamatan yang terdiri atas perusahaan manufaktur yang terdaftar di Bursa Efek Indonesia periode 2012-2018, b). Struktur Modal (DER) memiliki nilai minimum sebesar 0,150 dan nilai maksimum sebesar 2,137. Nilai minimum tersebut dimiliki oleh perusahaan PT Duta Pertiwi Nusantara Tbk pada tahun 2013 dan PT Mandom Indonesia Tbk tahun 2012, sedangkan nilai maksimum tersebut dimiliki oleh PT Unilever Indonesia Tbk pada tahun 2013. Secara keseluruhan diperoleh rata-rata sebesar 0,617 dengan deviasi standar sebesar 0,509 , c). Komisaris Asing memiliki nilai minimum sebesar 0,2 dan nilai maksimum sebesar 0,7. Nilai minimum tersebut dimiliki oleh perusahaan PT Unilever Indonesia Tbk pada tahun 2012 dan 2013, sedangkan nilai maksimum dimiliki PT Astra International Tbk pada tahun 2018. Secara keseluruhan diperoleh rata-rata sebesar 0,514 dengan deviasi standar sebesar 0,136, d). Direksi Asing memiliki nilai minimum sebesar 0,090 dan nilai maksimum sebesar 0,642. Nilai minimum tersebut dimiliki oleh perusahaan PT Astra International Tbk pada tahun 2016, sedangkan nilai maksimum dimiliki PT Mandom Indonesia Tbk pada tahun 2017 dan 2018. Secara keseluruhan diperoleh ratarata sebesar 0,411 dengan deviasi standar sebesar 0,187, e). Pertumbuhan Penjualan (GROWTH) memiliki nilai minimum sebesar $-0,086$ dan nilai maksimum sebesar 0,244. Nilai minimum tersebut dimiliki oleh perusahaan PT Astra International Tbk pada tahun 2015 dan PT Duta Pertiwi Nusantara Tbk tahun 2012, sedangkan nilai maksimum dimiliki PT Lion Metal Works Tbk pada tahun 2012. Secara keseluruhan diperoleh rata-rata sebesar 0,078 dengan deviasi standar sebesar 0,082, f). Effective Tax Rate (ETR) memiliki nilai minimum sebesar 0,066 dan nilai maksimum sebesar 0,539. Nilai minimum tersebut dimiliki oleh perusahaan PT Mandom Indonesia Tbk pada tahun 2015, sedangkan nilai maksimum dimiliki PT Lion Metal Works Tbk pada tahun 2017. Secara keseluruhan diperoleh rata-rata sebesar 0,256 dengan deviasi standar sebesar 0,084, g). Dividend Payout Ratio (DPR) memiliki nilai minimum sebesar 0,074 dan nilai maksimum sebesar 2,222. Nilai minimum tersebut dimiliki oleh perusahaan PT Asahimas Flat Glass Tbk pada tahun 2014, sedangkan nilai maksimum dimiliki PT Lion Metal Works Tbk pada tahun 2017. Secara keseluruhan diperoleh rata-rata sebesar 0,482 dengan deviasi standar sebesar 0,483, h). Kepemilikan Manajerial memiliki nilai minimum sebesar 0,00 dan nilai maksimum sebesar 0,15. Nilai minimum tersebut dimiliki oleh perusahaan PT Merck Tbk pada tahun 2016 dan 2017, sedangkan nilai maksimum dimiliki PT Astra International 
Tbk pada tahun 2014. Secara keseluruhan diperoleh rata-rata sebesar 0,005 dengan deviasi standar sebesar 0,026, i). Kepemilikan Institusional memiliki nilai minimum sebesar 0,501 dan nilai maksimum sebesar 0,866 . Nilai minimum tersebut dimiliki oleh perusahaan PT Astra International Tbk pada tahun 2012-2018, sedangkan nilai maksimum dimiliki PT Merck Tbk pada tahun 2016 dan 2017. Secara keseluruhan diperoleh rata-rata sebesar 0,693 dengan deviasi standar sebesar 0,144 .

\section{Uji Asumsi Klasik}

Uji asumsi klasik merupakan cara untuk mengetahui apakah model regresi yang digunakan dapat menghasilkan hasil yang baik. Jika telah memenuhi asumsi klasik, berarti model regresi ideal (tidak bias). Dalam analisis regresi terdapat beberapa asumsi yang digunakan untuk menunjukkan bahwa persamaan regresi yang digunakan dapat digunakan untuk memprediksi hubungan antar variabel. Uji asumsi klasik yang digunakan adalah uji normalitas, uji multikolinieritas, uji autokorelasi dan uji heterokedastisitas. Nilai signifikansi yang dipakai dalam penelitian ini adalah $5 \%$ atau tingkat kepercayaan 95\%.

\section{Uji Normalitas}

Uji normalitas bertujuan untuk menguji apakah dalam sebuah model regresi, variabel dependen dan variabel independen memiliki distribusi normal atau tidak. Seperti diketahui bahwa Uji $t$ dan Uji $F$ mengasumsikan bahwa nilai residual memiliki ditribusi normal. Kalau asumsi dilanggar, maka uji statistik menjadi tidak valid untuk jumlah sampel kecil (Ghozali, 2013). Uji normalitas penelitian ini menggunakan analisis grafik dengan normal probability plot dalam menentukan normalitas data.

Pada Gambar 1 terlihat bahwa titik-titik yang ada mengikuti garis. Hal ini menunjukkan bahwa data dalam penelitian ini berdistribusi normal. Uji normalitas penting untuk memastikan bahwa data dalam penelitian berdistribusi normal (Ghozali, 2013).

Normal P-P Plot of Regression Standardized Residual

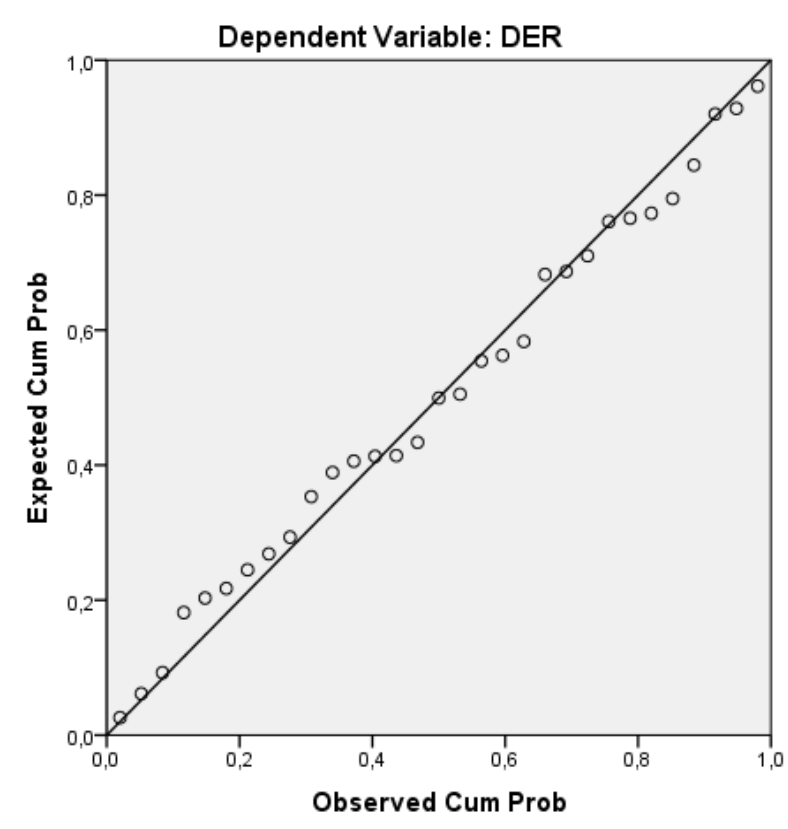

Gambar 1

Uji Normalitas

Sumber: Data telah diolah

\section{Uji Multikolinearitas}

Pengujian Multikolinearitas menggunakan Tolerance dan Variance Inflation Factor (VIF). Jika nilai tolerance lebih dari 0,1 dan VIF tidak lebih dari 10 maka variabel tersebut tidak mempunyai persoalan multikolinearitas dengan variabel bebas lainnya. Hasil uji multikolenaritas dapat dilihat pada Tabel 2.

Dari Tabel 2 dapat diketahui bahwa angka VIF berada di bawah angka 10\% dimana standar error dalam penelitian ini ditetapkan. Hasil ini menunjukkan bahwa model dalam penelitian ini bebas dari multikolinieritas. Multikolinieritas merupakan asumsi klasik yang harus dipenuhi untuk memastikan bahwa tidak ada korelasi yang terjadi antar variabel independen (Ghozali, 2013). 
Tabel 2

Hasil Uji Multikolinieritas

\begin{tabular}{cccccc}
\hline \hline \multirow{3}{*}{ Model Unstandardized Coefficients } & \multicolumn{2}{c}{ Collinearity Statistic } \\
\cline { 2 - 6 } & B & \multicolumn{2}{c}{ Std. Error } & Tolerance & VIF \\
\hline (Constant) & 1.368 & .485 & & \\
KA & -1.299 & .479 & .689 & 1.451 \\
DA & -2.313 & .386 & .564 & 1.772 \\
Growth & .749 & .722 & .841 & 1.189 \\
ETR & -.167 & 1.198 & .287 & 3.479 \\
DPR & .418 & .200 & .315 & 3.175 \\
KM & -.683 & 2.136 & .893 & 1.120 \\
KI & .946 & .559 & .452 & 2.214 \\
\hline
\end{tabular}

\section{Uji Autokorelasi}

Uji autokorelasi bertujuan untuk mengetahui apakah dalam suatu model regresi linier terdapat korelasi antara pengganggu pada periode $t$ dengan kesalahan pada periode $\mathrm{t}-1$ (sebelumnya). Autokorelasi muncul akibat observasi yang berurutan sepanjang waktu berkaitan satu sama lain. Masalah ini timbul karena residual tidak bebas dari satu observasi ke observasi lainnya.

Alat analisis yang digunakan adalah uji Durbin-Watson. Uji Durbin-Watson hanya digunakan untuk autokorelasi tingkat satu dan mensyaratkan adanya konstanta dalam model regresi. Model regresi yang baik adalah model regresi yang bebas dari auto- korelasi. Terdapat batas nilai dari metode Durbin-Watson untuk menarik kesimpulan uji autokorelasi (Ghozali 2011: 48), yaitu:

a. Angka D-W di bawah -2 berarti ada autokorelasi positif.

b. Angka D-W di antara -2 sampai +2 berarti tidak ada autokorelasi.

c. Angka D-W di atas +2 berarti ada autokorelasi negatif.

Hasil uji autokorelasi dapat dilihat pada Table 3. Berdasarkan Tabel 3, dapat diketahui bahwa nilai uji autokorelasi menunjukkan nilai Durbin Watson sebesar 0,590 di antara -2 dan +2 . Maka dapat disimpulkan bahwa model persamaan regresi dalam penelitian ini tidak mengandung masalah autokorelasi.

Tabel 3

Uji Autokorelasi

\begin{tabular}{ccccc}
\hline \hline \multicolumn{5}{c}{ Model Summary $^{\mathbf{b}}$} \\
\hline $\mathbf{R}$ & $\mathbf{R}$ Square & Adjusted R Square & Std. Error of the Estimate & Durbin Watson \\
\hline $.859^{\mathrm{a}}$ & .738 & .659 & .298 & .590 \\
\hline
\end{tabular}

a. Predictors: (Constant), KI, DPR, KM, GROWTH,

Komisaris Asing, Direksi Asing, ETR

b. Dependent Variable: DER

\section{Uji Heteroskedastisitas}

Uji heteroskedastisitas bertujuan menguji apakah dalam model regresi terjadi ketidaksamaan varian dari residual satu pengamatan ke pengamatan yang lain. Jika variance dari residual satu pengamatan ke pengamatan yang lain tetap, maka disebut homoskedastisitas dan jika berbeda disebut heteroskedastisitas. Model regresi yang baik adalah yang homoskedastisitas, atau tidak terjadi heteroskedastisitas (Ghozali, 2006). Uji heteroskedastisitas dalam penelitian ini 
menggunakan grafik scatterplot. Model regresi dikatakan homoskedastisitas apabila titik-titik dalam grafik scatterplot tidak membentuk pola tertentu dan menyebar secara acak baik di atas maupun di bawah angka 0 pada sumbu Y. Uji heteroskedastisitas dalam penelitian ini menggunakan analisis grafik yang disajikan pada gambar 2 .

Scatterplot

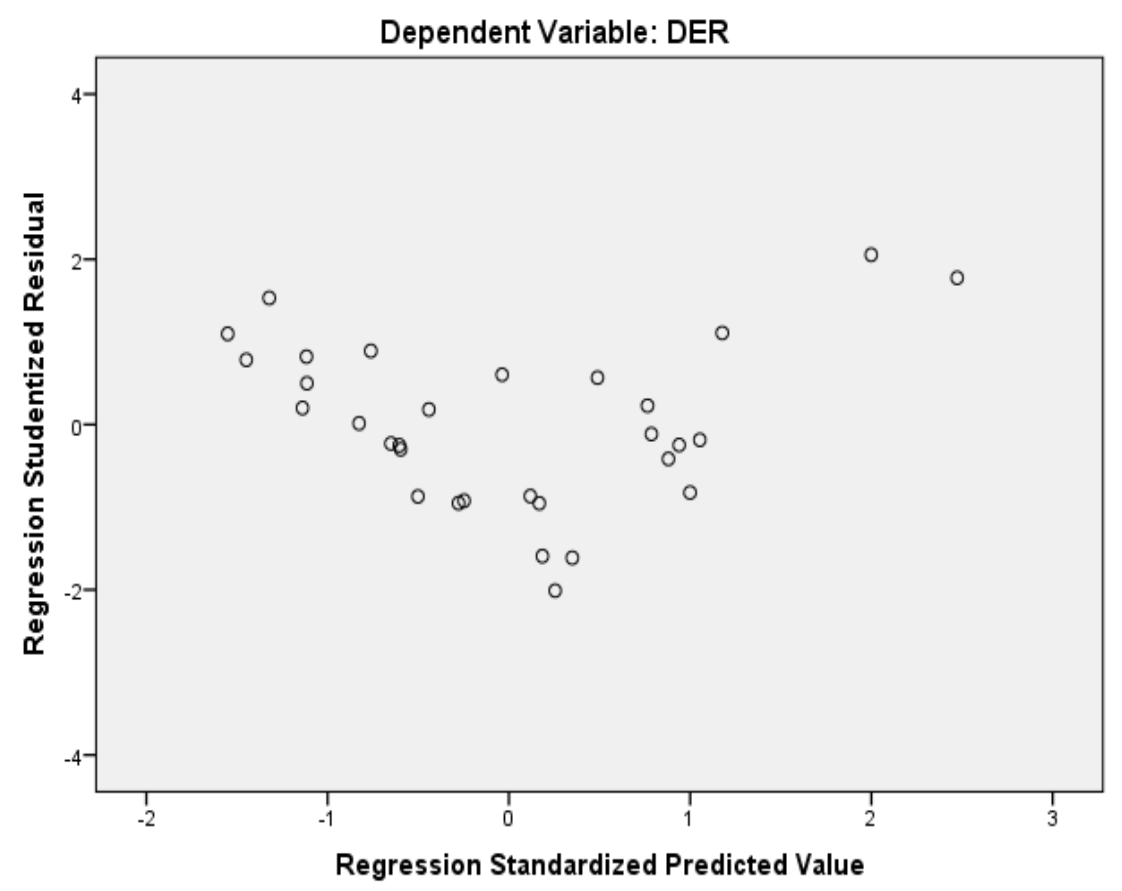

Gambar 2

Uji Heterokedastisitas

Sumber: Data telah diolah

Dari Gambar 2 dapat diketahui bahwa titik-titik pada gambar tersebar secara acak. Hal ini menunjukkan bahwa model dalam penelitian ini bebas dari heterokedastisitas. Uji heterokedastisitas merupakan uji asumsi klasik yang ditujukan untuk mengetahui ketidaksamaan variance dalam suatu model penelitian (Ghozali, 2013).

\section{Analisis Regresi Linier Berganda}

Persamaan regresi berganda ini dilakukan untuk mengujii pengaruh struktur modal, karakteristik perusahaan, dan struktur kepemilikan terhadap kinerja perusaha an. Hasil analisis regresi linier berganda disajikan pada Tabel 4.

Dari Tabel 4 dapat diketahui bahwa nilai sig dari variabel Komisaris Asing Asing lebih kecil dari standar error yang ditetapkan dalam penelitian ini sebesar $5 \%(0,05)$. Hal ini menujukkan bahwa Koefisien regresi Direksi Asing menunjukkan nilai signifikansi sebesar 0,012. Nilai signifikansi sebesar 0,012 lebih kecil dari 0,05 berarti bahwa variabel Komisaris Asing secara parsial memiliki pengaruh signifikan. Meskipun menurut Pedoman Umum KNKG (2006) menyatakan bahwa Dewan Komisaris tidak memiliki wewenang dalam pengambilan keputusan operasional dan kegiatan yang dilakukan perusahaan, namun pada kenyataannya Dewan Komisaris kemungkinan memiliki pengaruh yang lebih besar dari pada Dewan Direksi dalam hal menentukan arah kebijakan perusahaan, terlebih jika ada Komisaris yang menjadi salah satu pemegang saham dan memiliki afiliasi dengan pemilik perusahaan (Pradono dan Widowati, 2016). Dewan komisaris asing sebagian besar direkrut dari negara yang sudah 
memiliki tata kelola perusahaan yang lebih baik sehingga keberadaan dewan komisaris asing dapat memberikan dan dapat menerapkan nilai-nilai pengelolaan perusahaan yang baik dari negara asalnya. Adanya dewan komisaris asing yang dapat meningkatkan monitoring terhadap perusahaan yang berasal dari komisaris yang independen dan mempunyai konflik yang lebih rendah (Saragih, 2019).

Tabel 4

Hasil Analisis Regresi Berganda

\begin{tabular}{|c|c|c|c|c|}
\hline & \multicolumn{2}{|c|}{ Unstandardized Coefficients } & \multirow[t]{2}{*}{$T$} & \multirow[t]{2}{*}{ Sig. } \\
\hline & B & Std. Error & & \\
\hline (Constant) & 1.368 & .485 & 2.819 & .010 \\
\hline Komisaris Asing & -1.299 & .479 & -2.710 & .012 \\
\hline Direksi Asing & -2.313 & .386 & -5.990 & .000 \\
\hline GROWTH & .749 & .722 & 1.036 & .311 \\
\hline ETR & -.167 & 1.198 & -.140 & .890 \\
\hline DPR & .418 & .200 & 2.086 & .048 \\
\hline KM & -.683 & 2.136 & -.320 & .752 \\
\hline KI & .946 & .559 & 1.693 & .104 \\
\hline
\end{tabular}

a. Dependent Variable: DER

Kondisi Indonesia pada saat ini yang menjadi negara berkembang, menjadikan Indonesia masih perlu adanya proses untuk melakukan perbaikan tata kelola perusahaan yang baik. Menurut Reese dan Weisbach (2002) keberadaan dewan komisaris asing pada suatu perusahaan dapat meningkatkan nilai perusahaan karena dapat meningkatkan pengawasan, lebih transparan dan lebih patuh pada aturan tata kelola perusahaan. Sesuai dengan agency theory, adanya pengawasan dapat mengurangi tindakan manajer untuk mensejahterakan keuntungan pribadi. Burns dan Scapens (2000) menjelaskan komisaris asing memiliki pengalaman yang lebih banyak mengenai kegiatan operasional perusahaan termasuk kompetisi yang harus dilakukan sehingga dapat memberikan nilai tambah bagi perusahaan melalui kinerja perusahaan yang meningkat. Perusahaan yang memiliki kinerja baik, diharapkan akan mendapatkan laba yang tinggi sehingga perusahaan akan menggunakan laba tersebut untuk pendanaan kegiatan operasional perusahaan supaya tidak menggunakan pendanaan eksternal salah satunya yaitu melalui utang. Tindakan ini mendukung pecking order theory yang lebih men- dahulukan pendanaan internal daripada pendanaan eksternal.

Nilai signifikansi Direksi Asing lebih besar dari standar error yang ditetapkan dalam penelitian sebesar $5 \%(0,05)$. Hal ini menunjukkan bahwa koefisien regresi Direksi Asing mempunyai nilai signifikan sebesar 0,000 . Nilai signifikansi sebesar 0,000 lebih kecil dari 0,05 menunjukkan bahwa variabel Direksi Asing secara parsial memiliki pengaruh yang signifikan. Penelitian dari (Gulamhussen dan Guerreiro, 2009), berpendapat bahwa anggota dewan yang berkewarganegaraan asing membawa pengetahuan baru, keahlian, objektivitas dan perbaikan dalam struktur organisasi dan efisiensi. Hal ini mengindikasikan bahwa perusahaan mempekerjakan direksi asing untuk memanfaatkan informasi dan pengetahuan yang dimiliki oleh orang tersebut. Sesuai dengan pecking order theory tindakan tersebut akan meningkatkan kinerja sehingga perusahaan akan menggunakan pendanaan internal terlebih dahulu untuk membiayai kegiatan operasional perusahaan, maka perusahaan tidak perlu untuk melakukan pendanaan dari eksternal, yaitu berupa utang. 
Sesuai dengan agency theory tanpa adanya pengawasan yang baik, para manajemen (agent) dapat bertindak untuk memaksimalkan kepentingan pribadinya. Keputusan yang diambil oleh dewan direksi memang sangat mempunyai pengaruh signifikan karena tingkat bonus yang akan diterima bergantung pada kinerja perusahaan (Pradono dan Widowati, 2016). Meskipun mempunyai indikasi terjadinya motif untuk mendapatkan bonus atau bayaran yang lebih tinggi, keberadaan anggota dewan direksi asing yang dipilih oleh perusahaan manufaktur yang listing di BEI terbukti tidak mempunyai pengaruh dalam memberikan perubahan yang dapat berdampak positif terhadap keputusan pendanaan yang dilakukan melalui utang.

Penelitian ini juga menggunakan pertumbuhan penjualan, effective tax rate, dividend payout ratio, kepemilikan manajerial, dan kepemilikan institusional sebagai variabel kontrol. Hasil analisis regresi berganda pada persamaan regresi dengan memasukkan variabel kontrol ke dalam model persamaan yaitu pertumbuhan penjualan (Growth) yang mempunyai nilai signifikan 0,311 menunjukkan tidak berpengaruh terhadap struktur modal (DER). Ini menunjukkan bahwa pertumbuhan penjualan yang tinggi tidak mempengaruhi struktur modal melalui kebijakan utang perusahaan. Effective Tax Rate (ETR) yang mempunyai nilai signifikan 0,890 menunjukkan tidak berpengaruh terhadap struktur modal (DER). Sesuai Widayanti et al. (2016) yang menyatakan bahwa pajak berpengaruh positif dan tidak signifikan terhadap struk- tur modal. Dividend Payout Ratio (DPR) yang mempunyai nilai signifikan 0,048 menunjukkan berpengaruh terhadap struktur modal (DER). Sesuai dengan penelitian Indahningrum dan Handayani (2009) yang menyatakan bahwa semakin tinggi dividen, maka akan semakin tinggi struktur modal perusahaan. Kepemilikan Manajerial (KM) yang mempunyai nilai signifikan 0,752 menunjukkan tidak berpengaruh terhadap struktur modal (DER). Sesuai dengan pe- nelitian (Indahningrum dan Handayani, 2009; Larasati, 2011; Surya dan Rahayuningsih, 2012). Kepemilikan Institusional (KI) yang mempunyai nilai signifikan 0,104 menunjukkan tidak berpengaruh terhadap struktur modal (DER).

\section{SIMPULAN DAN SARAN \\ Simpulan}

Simpulan pada penelitian ini bahwa semua variabel independen yaitu Komisaris Asing dan Direksi Asing berpengaruh signifikan terhadap Struktur Modal. Adanya perusahaan memiliki komisaris dan direksi asing dapat membantu perusahaan untuk melakukan pengawasan dan mempunyai lebih banyak lagi pengetahuan dari pengalaman yang dimiliki dari berbagai negara asalnya sehingga dapat meminimalisir tindakan manajer yang dapat melakukan keputusan pendanaan yang lebih besar dari pendanaan eksternal, salah satunya berupa utang.

\section{Saran}

Saran untuk penelitian selanjutnya yaitu untuk menggunakan perusahaan yang lebih banyak tidak hanya perusahaan manufaktur saja untuk memberikan hasil dapat menjelaskan variabel yang digunakan dan untuk para organ perusahaan yaitu komisaris dan direksi agar lebih memperhatikan faktorfaktor eksternal seperti karaktersik perusahaan untuk melakukan keputusan pendanaan yang sesuai, supaya perusahaan tidak melakukan kebijakan yang dapat merugikan perusahaan.

\section{DAFTAR PUSTAKA}

Alijoyo, A., dan Zaini, S. 2004. Komisaris Independen: Penggerak Praktik GCG di Perusahaan. Jakarta.

Apriada, K. 2013. Pengaruh Struktur Kepemilikan Saham, Struktur Modal dan Profitabilitas Pada Nilai Perusahaan. (Tesis). Universitas Udayana, Denpasar.

Ararat, M. e. a. 2010. Impact of Board Diversity on Boards' Monitoring Intensity and Firm Performance: Evidence 
from the Istanbul Stock Exchange JEL Classification: G3, J16, L25.

Astuti, K. D., Retnowati, W., dan, dan Rosyid, A. 2015. Pengaruh Struktur Modal Terhadap Profitabilitas (Studi Pada Perusahaan Go Publik Yang Menjadi 100 Perusahaan Terbaik Versi Majalah Fortune Indonesia Periode Tahun 2010-2012). Jurnal Akuntansi: Kajian Ilmiah Akuntansi (JAK) 2(1): 49-60.

Azhagaiah, R., dan Gavoury, C. 2011. The Impact of Capital Structure on Profitability with Special Reference to IT Industry in India. Managing Global Transitions: International Research Journal 9(4).

Brigham, E., dan Ehrhardt, M. 2011. Financial Management: Theory and Practice 13th Edition. South-Western : Cengage Learning.

Cambrea, D. R., Lussana, G., Quarato, F., dan Varacca Capello, P. 2017. Top Management Team Diversity and Firm Performance: Empirical Evidence from the Fashion and Luxury Industry. Corporate Ownership and Control 15: 325340.

Choi, H. M., Sul, W., dan, dan Min, S. K. 2012. Foreign Board Membership and Firm Value in Korea. Management Decision, 50(2): $207-233$.

Denziana, A., dan Yunggo, E. D. 2017. Pengaruh Profitabilitas, Struktur Aktiva, Dan Ukuran Perusahaan Terhadap Struktur Modal Perusahaan Pada Perusahaan Real Estate And Property Yang Terdaftar Di Bursa Efek Indonesia Tahun 2015. Jurnal Akuntansi dan Keuangan 8(1).

Firmanullah, N., dan, Darsono. 2017. FaktorFaktor Yang Mempengaruhi Struktur Modal Di Perusahaan Indo- nesia (Pada Perusahaan Manufaktur Yang Terdaftar Di BEI Tahun 2011-2014). Diponegoro Journal of Accounting 6(3): 1-9.

Firnanti, F. 2011. Faktor-Faktor yang Mempengaruhi Struktur Modal Perusahaan Manufaktur di Bursa Efek Indonesia. Jurnal Bisnis dan Akuntansi 13(2): 119-128.
Ghozali, I. 2013. Aplikasi Analisis Multivariate dengan Program SPSS, Edisi ketujuh. Badan Penerbit Universitas Diponegoro (BPUD). Semarang.

Gulamhussen, M. A., dan , dan Guerreiro, L. 2009. The Influence of Foreign Equity and Board Membership on Corporate Strategy and Internal Cost Management in Portuguese Banks. Management Accounting Research 20(1): 6-17.

Harmono. 2009. Manajemen Keuangan. Bumi Aksara. Jakarta.

Hartono, B. 2016. Pengaruh Struktur Modal Dan Profitabilitas Terhadap Nilai Perusahaan Pada Perusahaan Properti Di Bursa Efek Indonesia Tahun 2008-2012. (Tesis). Universitas Lampung, Bandar Lampung.

Husnan, S. 2000. Manajemen Keuangan-Teori dan Penerapan (Keputusan Jangka Panjang). BPFE. Yogyakarta.

Indahningrum, R. P., dan Handayani, R. 2009. Pengaruh Kepemilikan Manajerial, Kepemilikan Institusional, Dividen, Pertumbuhan Perusahaan, Free Cash Flow, dan Profitabilitas terhadap Kebijakan Utang Perusahaan. Jurnal Bisnis dan Akuntansi 11(3): 189-207.

Jensen, M. C., dan dan Meckling, W. H. 1976. Theory of the Firm: Managerial Behavior, Agency Costs and Ownership Structure. Journal of Financial Economics 3(4): 305-360.

Kesuma, A. 2009. Analisis Faktor yang Mempengaruhi Struktur Modal Serta Pengaruhnya Terhadap Harga Saham Perusahaan Real Estate yang Go Public di Bursa Efek Indonesia. Jurnal Manajemen dan Kewirausahaan 11(1): 38-45.

KNKG, K. 2006. Pedoman Umum Good Corporate Governance di Indonesia.

Kurnia, D. 2017. Analisis signifikansi leverage dan kebijakan deviden terhadap nilai perusahaan. Jurnal Akuntansi: Kajian Ilmiah Akuntansi (JAK) 4(2).

Larasati, E. 2011. Pengaruh Kepemilikan Manajerial, Kepemilikan Institusional dan Kebijakan Dividen terhadap 
Kebijakan Utang Perusahaan. Jurnal Ekonomi Bisnis 16(2): 103-107.

Lessy, D. A. 2016. Pengaruh Ukuran Perusahaan, Likuiditas, Profitabilitas, dan Struktur Aktiva terhadap Struktur Modal pada Perusahaan Manufaktur yang Terdaftar di Bursa Efek Indonesia. (Skripsi), Universitas Negeri Yogyakarta.

Mayangsari, S. 2001. Analisis Faktor-faktor yang Mempengaruhi Keputusan Pendanaan Perusahaan: Pengujian Pecking Order Hypotesis. Media Riset Akuntansi, Auditing, dan Informasi 1(3): 1-26.

Myers, S., dan Maljuf, N. 1984. Corporate Financing and Investment Decision When Firm Have Information That Investor Do Not Have Journal of Financial Economics 13: 187-222.

Nikmah, F. I., dan Arifianto, S. 2013. Pengaruh Dewan Komisaris Asing, Dewan Komisaris Independen Dan Kepemilikan Saham Asing Terhadap Nilai Perusahaan (Studi Empiris Pada Perusahaan Manufaktur Yang Terdaftar Di Bei Tahun 2009-2011). Jurnal Fairness 3(2): 95-103.

Nugroho, A. S. 2006. Analisis Faktor-Faktor yang Mempengaruhi Struktur Modal Perusahaan Properti yang Go-Public di Bursa Efek Jakarta Untuk Periode Tahun 1994-2004. (Tesis). Universitas Diponegoro, Semarang.

Oktaviani, A. 2017. Pengaruh Board Diversity pada Dewan Direksi terhadap Struktur Modal Perusahaan di Indonesia (Studi pada Perusahaan Jasa yang Terdaftar di Bursa Efek Indonesia Periode 2011-2015). (Skripsi), Universitas Andalas, Padang.

Polovina, N., dan Peasnell, K. 2015. The effect of foreign management and board membership on the performance of foreign acquired Turkish banks. International Journal of Managerial Finance, 11(3): 359-387.

Pradono, N. S. H. d., dan Widowati, E. H. 2016. Pengaruh Komisaris Asing, Direktur Asing dan Kepemilikan Asing terhadap Kinerja Intellectual Capital. KINERJA 20(2): 132-148.
Prasetia, T. E., Tommy, P., dan, dan Saerang, I. S. 2014. Struktur Modal, Ukuran Perusahaan Dan Risiko Perusahaan Terhadap Nilai Perusahaan Otomotif Yang Terdaftar Di BEI. Jurnal EMBA: Jurnal Riset Ekonomi, Manajemen, Bisnis dan Akuntansi 2(2).

Reese, J., William, A., dan, Weisbach, M. S. 2002. Protection of minority shareholder interests, cross-listings in the United States, and subsequent equity offerings. Journal of financial economics 66(1): 65-104.

Riyanto. 2011. Dasar-dasar Pembelanjaan Perusahaan. BPFE. Yogyakarta.

Saragih, N. R. 2019. Pengaruh Direktur Asing, Komisaris Asing, dan Kepemilikan Asing Terhadap Kinerja Perusahaan (Studi Empiris pada Perusahaan Manufaktur yang Terdaftar di BEI Periode 2014-2017). Universitas Muhammadiyah Surakarta, Surakarta.

Septiani, A. 2005. Faktor-faktor yang Mempengaruhi Ketepatan Waktu Pelaporan Keuangan Pada Pasar Modal yang Sedang Berkembang: Perspektif Teori Pengumpulan. (Tesis). Universitas Diponegoro, Semarang.

Setiawan, D., Hapsari, R., T., dan Wibawa, A. 2018. Dampak Karakteristik Dewan Direksi Terhadap Pengungkapan Corporate Social Responsibility Pada Perusahaan Pertambangan Di Indonesia. MIX: Jurnal Ilmiah Manajemen 8(1): 1-15.

Sugiarto. 2009. Struktur Modal, Struktur Kepemilikan Perusahaan, Permasalahan Keagenan dan Informasi Asimetri. Graha Ilmu. Yogyakarta.

Surya, D., dan Rahayuningsih, D. A. 2012. Faktor-Faktor yang Mempengaruhi Kebijakan Utang Perusahaan Non Keuangan yang Terdaftar dalam Bursa Efek Indonesia. Jurnal Bisnis dan Akuntansi 14(3): 213-225.

Susila, I. M. P., dan Prena, G. D. 2019. Pengaruh Keputusan Pendanaan, Kebijakan Deviden, Profitabilitas Dan Corporate Social Responsibility Ter- 
hadap Nilai Perusahaan. Jurnal Akuntansi: Kajian Ilmiah Akuntansi (JAK) 6(1): 80-87.

Swartz, N. P., dan Firer, S. 2005. Board Structure dan Intellectual Capital Performance in South Africa. Meditari Accountancy Research 13(2): 145-166.

Toyyibah, J. 2012. Pengaruh Karateristik Diversitas Komisaris dan Direksi terhadap Kinerja Keuangan (Studi Empiris Perusahaan yang Terdaftar di Bursa Efek Indonesia Tahun 2010. Skripsi. Akuntansi FE Universitas Indonesia.

Triani, T. 2018. Analisis Pengaruh Keberagaman Dewan Komisaris dan Struktur Kepemilikan Perusahaan terhadap Kualitas Pengungkapan Corpo- rate Social Responsibility. Jurnal Aset 20(1): 57-65.

Ujunwa, A. 2012. Board Characteristics and the Financial Performance of Nigerian Quoted Firms. Corporate Governance: The international journal of business in society, 12(5): 656-674.

Wiagustini, N. L. P. 2010. Dasar-Dasar Manajemen Keuangan. Udayana: University Press Denpasar.

Widayanti, L. P., Triaryati, N., dan Abundanti, N. 2016. Pengaruh Profitabilitas, Tingkat Pertumbuhan Perusahaan, Likuiditas, dan Pajak terhadap Struktur Modal pada Sektor Pariwisata. E-Jurnal Manajemen 5(6): 3761-3793. 